University of South Carolina

Scholar Commons

$11-2017$

\title{
Social Imaginaries and the Theory of the Normative Utterance
}

Meili Steele

University of South Carolina - Columbia, steelem@sc.edu

Follow this and additional works at: https://scholarcommons.sc.edu/engl_facpub

Part of the Philosophy Commons

\section{Publication Info}

Postprint version. Published in Philosophy and Social Criticism, Volume 43, Issue 10, 2017, pages 1045-1071.

(c) The Author, 2017

This Article is brought to you by the English Language and Literatures, Department of at Scholar Commons. It has been accepted for inclusion in Faculty Publications by an authorized administrator of Scholar Commons. For more information, please contact dillarda@mailbox.sc.edu. 
Philosophy and Social Criticism (July 2017)

Social Imaginaries and the Theory of the Normative Utterance ${ }^{1}$

\section{Meili Steele}

Theorists of the social imaginary, such as Benedict Anderson, Charles Taylor, Cornelius Castoriadis, and Marcel Gauchet have given us new ways to talk about the structures of the shared meanings and practices of the West. As a group, they have directed their arguments against the narrow horizons of meaning deployed by deliberative political theories in developing their basic normative concepts and principles. Anderson speaks of the new shapes of time and space provided by the novel and newspaper; Taylor and Gauchet discuss the ontological importance of the emergence of secularity, the public sphere, popular sovereignty, and the market; Castoriadis places creative collective imagination at the center of his work. They have provided an alternative to the oscillation between the constructivism of John Rawls, Jürgen Habermas, and Christine Korsgaard and the realism of Raymond Guess, Raymond Williams, and others. ${ }^{2}$ Theorists of the imaginary have enabled us to think about normatively charged collective imaginaries as logically prior to the construction of normative principles. ${ }^{3}$

What theorists of the imaginary have not done is make specific connections between the ontological background of social imaginaries and the normative utterance. This lacuna has left them vulnerable to the charges of "normative deficit" and vagueness that Habermas and others famously make against philosophies of "world disclosure."4 To be sure, philosophers of the imaginary are careful to supplement third-person accounts of political culture with phenomenological descriptions; however, when theorists of the imaginary move from the 
common background provided by imaginaries to the first- and second person, the focus is usually on the imagination as a faculty rather than on the new conception of the normative utterance and political dialogue that follows from an understanding of the social imaginary. ${ }^{5}$ I will consider the relationship of social imaginaries to individual utterances so that we do not have the individual imagination set against the social context, but the utterance as reproducing and/or intervening in the imaginary structures. In this view, normativity is not expressed in the propositional form of the Rawlsian or Habermasian justification, but through a complex engagement with the worldhood that informs normative judgments. Looking at the normative utterance through the lens of social imaginaries enables us to engage the background structures that subtend discrete utterances, and this engagement requires richer forms of argument than what we find in constructivist or realist conceptions of normativity.

I will proceed in three steps. I begin by contrasting the constructivist approach with Charles Taylor's philosophy of social imaginaries and world disclosure since his work makes an explicit link between ontology and utterance. I then bring out the shortcomings of Taylor's approach by examining briefly his debate with Robert Brandom over world-disclosure and the exchange of reasons. This analysis gives rise to my own account of the normative utterance, which I develop by looking at two examples. The first is a short story—Susan Glaspell's “A Jury of Her Peers"- that dramatizes the discovery of fissures in what was taken to be a shared background and that articulates the normative relevance of these fissures by arguing through and with the social imaginary rather than normative propositions. I then show how this kind of reading exposes the inadequacies in Paul Ricoeur's philosophy of narrative, which Taylor-and many other philosophers - endorse and which occludes the normative claims of narrative utterances. The second example looks at two very different ways of engaging the American 
imaginary surrounding race: Barack Obama's “A More Perfect Union,” and Ta-Nahisi Coates's normative challenge to Obama's discursive form, Between the World and Me. Obama's speech reanimates a canonical normative discursive framework for understanding race, Brown v Board of Education, which continues to exercise its power over public debate. Coates attacks this framework not by analyzing a principle of justice but by displaying the unacknowledged conflicts in the imaginary, conflicts that go unrecognized by whites and that blacks struggle to articulate. He writes in the form of a letter to his son, in which he deploys various kinds of discourse--phenomenological description, narrative, and sociological generalization--to give a portrait of racial division in contemporary American life. In addressing the imaginary, Coates reveals the failure of our current language of facts and norms.

\section{Thrownness and Social Imaginaries}

In the hermeneutic perspective initiated by Heidegger, we are thrown into the world, into social imaginaries so that morality builds on norms that are already in place, on norms which are not constructed. In other words, normativity emerges through the social imaginary in a way that is logically prior to the conceptual formulations of ethical and political philosophy. ${ }^{6}$ What Taylor and the other philosophers of the imaginary cited above have done is take this transcendental hermeneutic point made by Heidegger and Gadamer about worldhood and refined the historiography with the help of work by historians and sociologists in order to examine the emergence and modification of particular collective historical shapes. Taylor says, "The social imaginary is not a set of ideas;" rather, the imaginary forms the background that makes sense of "the practices of a society [...Thus,] the notion of a moral order goes beyond some proposed schedule of norms that ought to govern our mutual relations and/or political life $[\ldots]$ The image of order carries not only a definition of what is right, but of the context in which it makes sense to strive for and hope to realize the right." ${ }^{7}$ The social imaginary concerns the 
ways that "ordinary people 'imagine' their social surroundings and this is often not expressed in theoretical terms but in images, stories, legends, etc.... The social imaginary is that common understanding which makes possible common practices and widely shared sense of legitimacy." These imaginaries form the background out of which we think and act but "which we do not entirely understand. To ascribe total personal responsibility to us for these is to want to leap out of the human condition." 9

Such a conception of normativity demands a very different form of questioning than the constructivist approach. In understanding and defending normative claims, we must locate ourselves in the space of historical imaginaries and argue through these imaginaries rather than finding principles to which all should agree. Hence, "the task of reason is to articulate this background, what we presuppose when we make a judgment that a certain form of life is truly worthwhile, or place our dignity in a certain achievement." ${ }^{10}$ These are the conditions of intentionality. ${ }^{11}$

We can see the relationship of the ontological background (the political) to politics in Taylor's work by looking quickly at A Secular Age. At the beginning of A Secular Age, he distinguishes three kinds of secularism. The concerns of philosophers of public reason are placed in "Secularity 1," which focuses on the retreat of religion from the common institutions and practices "most obviously, but not only, the state." ${ }^{\prime 2}$ This is the normative, political secularism of public reason that addresses controversies such as the wearing of headscarves to school or the display of religious symbols on state grounds. A second sense of secularity refers to the decline of religious belief and practice - people no longer going to church, synagogue or mosque, for instance. This sociological approach is often called "secularization." The third and most important sense of secularity for Taylor concerns the shift in "the conditions of belief" since this 
sense gives a place to the ontological history he finds important. In this view, the "shift to secularity consists of a move from a society where belief in God is unchallenged and unproblematic to one in which it is understood to be one option among others, and frequently not the easiest to embrace." ${ }^{13}$ In other words, Taylor wants to examine the shift "which takes us from a society in which it was virtually impossible not to believe in God, to one in which faith, even for the staunchest believers, is one possibility among others." ${ }^{14}$ Taylor's claim for Secularity 3 is not simply that this is a better description of contemporary society's understanding of religion and secularity. His claim is philosophical. Although we may have much to learn from researchers in Secularity 1 and 2, they have left out the worldhood of the world. Sociologists may focus on gathering statistics about church or synagogue attendance as evidence of secularization, while political philosophers may assert the uncontroversial "fact of pluralism" in order to focus on the construction of norms of mutual accommodation. ${ }^{15}$ But before these facts or norms can appear, they require a background that lets them show up for us as phenomena. Of course, people can bring different ideas and attitudes to a secularity, "but what they do not bring into the negotiations is the set of ideas and norms constitutive of [secularity itself]. This must be the common property of society before there can be any question of [debate]. Hence, they are not subjective meanings, the property of one or some individual, but rather intersubjective meanings, which are constitutive of the social matrix in which individuals find themselves and act." ${ }^{16}$ Hence, Taylor's question is: what are the background assumptions, practices, languages, etc. that make the contemporary experience of the secular and the religious possible, for believers, agnostics, and atheists? We stand in a normed world of social imaginaries that cannot be set aside to get clear about particular normative concepts. 
Taylor does a genealogy of Western secularity that gives a new account of how our current background assumptions emerged, drawing out new historical richness and complexity that becomes available and normatively relevant through this problematic. We cannot just toss in a vague, schematic historical tale about how secularity emerged from the wars of religion and modern science in order to focus on the principles of public reason. ${ }^{17}$ Rather, "our sense of where we are is crucially defined in part by a story of how we got there.... And just because we describe where we are in relating a journey, we can misdescribe it grievously by misidentifying the itinerary. That is what the subtraction accounts of modernity have in fact done. To get straight where we are, we have to go back and tell the story properly." ${ }^{18}$ To get oriented to the world and our place in it requires more than abstract principles — such as "the separation of church and state"-for they block out the massive background that shapes reasoning. Normativity cannot swing free from contestable historical accounts of how our selfunderstandings came about because it is woven from specific social imaginaries. Hence, Taylor wants to begin reasoning by reopening the assumptions of modernity and displaying the complex, conflicted historical inheritance that lies behind current usage.

The articulation of background social imaginaries brings in the third-person point of view that is excluded by the constructivist view, and it joins up with Taylor's long-standing objection to such theories of practical reason because they "cannot articulate the background understanding surrounding any conviction that we ought not act in this or that way." ${ }^{19}$ However, we need to distinguish two kinds of articulations or "world disclosures" that Taylor sometimes conflates. ${ }^{20}$ On the one hand, there is articulation "of an already interpreted, symbolically structured world; the world, that is, within which we always already find ourselves,"21 and, on the other hand, there is the utterance, the "reflective disclosure." The articulation of background is concerned 
with our passive relationship to structures of intelligibility, such as we find in Taylor's discussion of the public sphere, popular sovereignty in Modern Social Imaginaries, or Secularity 3 in A Secular Age. Here the language of articulation is a socio-historical language of social imaginaries. These structures can be characterized in various ways, and Taylor slides-much as the narrator of a third-person novel does — between sociological explanations, what he calls "neo-Durkheimian moments," and articulations that are close to phenomenological description of individual and collective experience displayed through everyday speech.

The utterance or "reflective disclosure" — and here I modify Kompridis's definition—is the intervention in the prereflective practices and structures of meaning by an utterance, work of art, a film, historical or philosophical text, etc. The individual makes claims through and against the social imaginaries in which she finds herself. Reflective disclosure reworks the languages and structures used to make sense of ourselves and the world, and these interventions can take the form of normative arguments, as we will see. The transcendental argument against constructivist arguments does not just show the relevance of background structures to our selfunderstanding; it authorizes new forms of argument. We are now ready for Taylor's debate with Brandom over just this issue.

\section{Problems with Intervention as World Disclosure}

In a recent debate on language and rationality, Taylor and Brandom agree on many of the holistic assumptions of hermeneutics—what Brandom calls "Gadamerian platitudes"—but differ on the relationship of world disclosure to conceptual understanding and the exchange of reasons. ${ }^{22}$ Brandom insists that we "draw a bright line between conceptual understanding and other kinds of symbolic disclosedness." ${ }^{23}$ In this view, "broadly symbolic [dimensions of language] in Cassirer's sense, are not conceptual in the narrow propositional sense that I render in terms of inference and reasons. ${ }^{24} \mathrm{He}$ clarifies this by drawing on Wittgenstein's well-known 
analogy of language as a city, "Language for [Wittgenstein] is all suburbs, merging imperceptibly into the surround and supporting countryside of linguistic practices, and having no downtown. But I think language does have a downtown, and that is the practice of giving and asking for reasons." 25 The practice of giving and asking for reasons swings free not only of symbolic uses but of particular forms of life.

Taylor, on the other hand, does not think we can isolate reason from giving disclosure in this way, "I remain convinced that the articulative [disclosive] cannot be peeled off from the public giving of and asking for reasons." ${ }^{26}$ Any exchange over "the factual state of things" can only make sense if we set them "in the context of our ability to operate through the whole range of symbolic forms." ${ }^{27}$ Hence, "there are certain matters which can't be properly explored without recourse to the disclosive dimension. There couldn't be an intelligent discussion of the beauty of landscape which didn't either deploy or draw on our familiarity with, say, certain paintings. There couldn't be a discussion of Christian piety which didn't draw on, say, the music of Bach, or certain hymns, or Chartres cathedral or an evocative life of Saint Francis." For Taylor, there is a continuum between pure assertion—e.g., "soup's on!"-—where something is asserted but nothing is disclosed, and pure disclosure-e.g., Chopin's Fantaisie-Impromptu in C Sharp Minor, which "articulates a certain as yet indefinable longing....A human possibility is articulated and disclosed here, but nothing is asserted." 28 Taylor gives artistic disclosure a privileged access to the distinctiveness of a form of life at the same time that he makes this disclosure ineffable. But this perspicacity does not have to define itself against conceptual understanding or the language of ordinary prose, as we will see.

Although Brandom and Taylor share a holistic critique of the Kantian understanding of the concept - according to which the institution of conceptual norms is separate from their 
application —-they develop different kinds of holism. ${ }^{29}$ For Brandom, the key is Hegelian reconstruction, "[T]he rationality of the current decision, its justifiability as a correct application of a concept, is secured by rationally reconstructing the tradition of its applications according to a certain model—by offering a selective, cumulative, expressively progressive genealogy of it. At each stage in its development, it is insofar as one takes the tradition to be rational, by a Whiggish rewriting of its history, that one makes the tradition be and have been rational...This is reason's march through history. In this way, as Hegel puts it, contingency is given necessity." 30 In his book on Hegel, Taylor states his opposition to this reconstructive logic of transparent concepts, insisting that "the clarity of our most explicit conceptual formulations reposes on a background of which we are not fully aware. ${ }^{\prime 31}$ Brandom concludes that Taylor is not a rationalist. ${ }^{32}$ While I agree with Taylor on the Hegelian question, his alternative does not provide a satisfying account of normativity.

Taylor focuses his attention on the Heideggerian point—-that logical forms of language depend upon a background - rather than connecting background and normativity into an adequate conception of language and argument. In theorizing the individual utterance, Taylor makes a move that is all too typical of both defenders and critics of world disclosure by defining disclosure against everyday speech and normativity. In lumping together various aesthetic works and ignoring the disclosive power of everyday language, he fails to address the normative claims of "disclosive" writing that could answer disclosure's critics. It is one thing to respect the insights provided by literary language: "We delude ourselves if we think a philosophical or critical language is somehow more hard-edged and more free from personal index than that of poets or novelists;" ${ }^{33}$ however, it is another to give literature blanket insight beyond challenge, ignoring the ways that literature can often be misleading, repulsive, or just stupid. By giving 
literature this vatic status, he gives weight to Christina Lafont's charge (cited in note 2 above) that "world disclosure seems unrevisable from within and inaccessible from without," a charge to which I will respond directly. ${ }^{34}$

Taylor follows the German hermeneutic tradition here, in placing art, particularly poetry, against prose and everyday speech. Wolf Lepenies notes that "the antithesis of literature and poetry has been maintained in all its severity only in Germany, where it has been exacerbated through an asociality of poetical production in principle, that even sees its chief task as being the 'refutation of the social." ${ }^{\prime 35}$ Gadamer, for instance, for all his emphasis on dialogue, still gives art privileged disclosive access to our being in the world in a way that exempts art from normative claims: "Prior to all conceptual scientific knowledge, the way in which we look upon the world, and upon our whole being-in-the-world, takes shape in art. ${ }^{{ }^{36}}$ Gadamer opposes poetry and philosophy to everyday language: "Poetry and philosophy are both set off from the exchange of language as it takes place in practical activity and in science." 37

The opposition of poetry and prose has meant hostility to the distinctive genre of modernity, the novel. The novel is attentive to the dynamic interplay of the multiple languages of public life, languages ignored by Heidegger and Gadamer. Taylor views the novel mostly through a sociological lens, in which the novel helps shape the modern sense of space and time and helps establish the dignity of everyday life (Sources of the Self, Part III). The language of literature is a poetic language for Taylor, a language tied to the search for spiritual significance, not to its relevance to public, normative debates. Much of his discussion of disclosure has a religious character to it, and we can see this in his emphasis on the connection between disclosure and epiphanic poetry in Sources of the Self and his emphasis on "fullness" in A Secular Age. 
In his new book, The Language Animal, the closest he comes to connecting imaginaries and normativity is when he discusses "accessive" and "existential" disclosure. Accessive disclosures “open a new range of phenomena to us, for instance terms to classify animals or trees." ${ }^{38}$ Existential disclosure offers "a new way of describing, or a new model for understanding, our human condition and the alternatives it opens for us..... We may come to this existential insight through meeting, or hearing about, some paradigmatic figure (the Buddha, St. Francis), or by reading a book about ethics or the meaning of life or (more often) by seeing a film." ${ }^{39}$ Existential disclosures are made available through the language of "portrayal" rather than the language of assertion-e.g., Dostoevsky's Devils (78). A “portrayal can be an alternative way of offering models to understand human life, alternative, that is to description. ${ }^{40} \mathrm{He}$ calls this mode "regestalting," but this way of talking takes away any argumentative or normative claim. In my view, such "regestalting" can be understood as normative revision that can play on the same field with principled argument.

Taylor similarly characterizes narratives by opposing them to assertions. He emphasizes how narratives cannot be translated into assertions rather than showing how narratives are woven into assertions and can challenge them: "Everybody would probably grant my first assertion above, that narrative constitutes a way of offering insight into causes, characters, values, alternative ways of being and the like. But many would baulk at the second affirmation that this form is unsubstitutable." ${ }^{41}$

In addition, Taylor blocks out the power of imaginaries to shape the concepts, with which they are imbricated. When speaking of the interaction of concepts and imaginaries, he speaks of concepts "trickling down" into imaginaries but does not examine the ways that imaginaries shape concepts: 
When a theory penetrates and transforms the social imaginary..., people take up, or are inducted into new practices. These are made sense of by the new outlook, the one first articulated in theory...but this process isn't just one sided; a theory making over a social imaginary. The theory in coming to make sense of the action is glossed, as it were, given a particular shape as the context of these practices. Rather like Kant's notion of an abstract category becoming 'schematized' when it is applied to reality in space and time, the theory is schematized in the dense sphere of common practice. ${ }^{42}$

This misstates relationship of concepts to imaginaries. The languages of the social imaginaries do not schematize concepts, for schematization ignores the dynamics of languages and dialogue in which imaginaries help produce concepts, reducing them to a derivative philosophical operation. Rethinking normativity involves thematizing and revising a package of concepts and imaginaries. Such a conception of the social is lost in the notion of schematization, which carries unfortunate Kantian baggage that renders imaginaries secondary. Imaginaries are not separate from the conceptual argument and should not be relegated to the secondary status, as my examples will show.

For all the richness of his two most recent books, The Language Animal and Retrieving Realism, Taylor never moves to integrate his views on language with social imaginaries. In fact, the idea of social imaginaries never appears in these works. ${ }^{43}$ These works are complex and interesting — I can hardly summarize them here — but they say nothing to contradict the critique I have advanced. In my view, social imaginaries inform our most basic practical engagements with the world and their relationship to particular utterances can be made visible and provide a space for a new conception of disclosure and practical reasoning.

\section{Reasoning through the Social Imaginary in Glaspell's “A Jury of Her Peers"}


Susan Glaspell’s short story “A Jury of Her Peers” (1917) offers a phenomenology of interpretation in a straightforward everyday language that opens the boundaries of art and everyday speech and shows how narratives can make normative arguments. The story dramatizes a "world historical" shift in the normative imaginary of gender, a shift that goes far beyond the formal political inclusion of women through the extension of the principle of equality, which was achieved three years after the story was published through the Nineteenth Amendment in 1920. The title of the story alludes to the debates that preceded its passage.

The tale begins when Mrs. Hale is called from her work in the kitchen to join her husband, Mr. Peters (the sheriff), and his wife. Mrs. Hale, the center of focalization for the thirdperson narrative, learns that Mr. Wright, the husband of an old friend, has been killed. The sheriff suspects that Mrs. Hale's friend Minnie has killed her husband. The group proceeds to the Wrights' home, where it splits up. The men go out to the barn to look for evidence that can establish a motive for Minnie, while the women wait in the kitchen. While sitting there, they encounter the "text" of Minnie's life - the dirty towels, the mishandled stitching on her quilt, the act of violence of which she is suspected, and so on. That is, the dominant tradition that the women bring to Minnie's house, a tradition that they share with their husbands, forms preunderstandings that do not help them reconstitute the self-understanding of the text. The men have called Minnie "mad," and the women at this point can articulate no other reading, even though they sense that more is at stake here for them.

Slowly the women start to put together an explanation of the strangeness of Minnie's text - the systematic psychological torture to which her husband subjected her, a torture that culminated in the strangulation of Minnie's double, her pet bird. The process of coming to this explanation forces them to transform the understandings of their own lives and indeed the 
gendered imaginaries of the time. Minnie's text asks them disturbing questions, not just the other way around.

They discover that Minnie's husband was not just "a cruel man" but also a typical one and that Minnie's response differs only in degree, not in kind, from the ones they have had but ignored or repressed. It is important that Mr. Wright commits no actionable offense. He merely brings into relief the norms that are already there, norms that inform the actions within many marriages. The story's off-stage narrator shows their complex interaction with the textsometimes it grabs them and sometimes they push it away — that is rarely made explicit in their consciousness or in dialogue. The women are not exchanging claims in discursive dialogue in which they use the constructed political concepts to unmask ideology. They are experiencing a challenging rupture - and Glaspell is displaying it —in the reigning package of concepts and imaginaries surrounding marriage and gender. The context of their reading - their moments of isolation interrupted by their husbands' condescending remarks about the triviality of women's occupations - helps foster their transformative reading. The women come to understand that the values and textures of their own lives are neither read nor recognized by their husbands and that the forces that drove Minnie mad operate around and within them as well. The women discover the narrow social space in which they have been channeled to live and the anger that they have been socialized to ignore.

The boundaries of their selves have been unraveled as Minnie's text not only speaks to them but for them: "It was as if something within her not herself had spoken, and it found in Mrs. Peters something that she did not know as herself." ${ }^{44}$ Interpretation in this story is dramatized as an event, not an act. When Mrs. Peters discovers the strangled bird, she does not just solve a detective's riddle; she reworks the fabric of her memory and identity. As she recalls 
and revises the story of what a boy with a hatchet had done to her cat many years ago, she gets back the rage of the past moment: "'If they hadn't held me back, I would have...." Minnie's text forces them to see themselves and their husbands in a way that requires a new language that gives distinctiveness and worth to their lives and that goes unread by the dominant culture. The women do not empathize with Minnie, for empathy implies a subject to subject model of reading that ignores the normative work of the story. The text develops a descriptive/normative language that did not yet exist so that we do not have normative principles on one side and the facts on the other. New normative languages make new facts and meanings available..$^{45}$

Unlike Minnie, they are able to create a way of speaking that unites them with each other and separates them from the men. They have formed a powerful normative language that gives them reasons to do something they never could have imagined before they arrived at the Wrights' house. They have created a "new space of reasons," to use Sellars's famous phrase. ${ }^{46}$ The story implicitly takes a stance with regard to existing imaginaries and in doing so creates its own space in which existing norms are engaged and modified.

Their interpretations open a new, hitherto unthinkable space of action: they choose to hide the bird (conceal evidence), betray their husbands, and break the law. There is nothing ineffable about this disclosure, but the reasons of the argument do not appear in terms of the principles of public reason, such as justice and equality. Certainly, such notions inform the background, but these conceptual principles are woven into the textures of their shared imaginaries. Indeed, concepts and imaginaries worked together to form an imprisoning discursive package that Minnie's text calls into question and pushes them to revise. The thirdperson narrator articulates the new space of understanding that emerges for them without ever reducing it to a conceptual label. 
Thus, in answer to Brandom's charge that world disclosure does not offer reasons, I would say that this story is Susan Glaspell's disclosive, argumentative reasoning. It offers a complex account of the discovery of violence embedded in one configuration of norms and meanings, of one configuration of reasoning giving. How does one go from not seeing domination to seeing it? Not through the application of a constructed principle, but by attending to the normative articulations made by Minnie's text, articulations that open up new ways of being in the world. The women are not "finally" understanding what the constructed principle of "equality" or "justice" means. They reason by tacking between accounts of their ontological background and the interpretive normative intervention that they make. In displaying the women's transformation in a story, Glaspell shows us how normative argument always depends on contestable assumptions in the background imaginaries and how we can thematize these assumptions and show their normative, argumentative relevance through narrative. This text also illustrates what is left out by thinking of the inclusion of women as the application of a principle that lets them vote and serve on juries, while not addressing the social imaginaries that shape their lives and society as a whole. The understanding of narrative in my analysis is quite different from Taylor's and from Paul Ricoeur's, which Taylor frequently cites. Since Ricoeur's view is widely accepted — and misleading - I will make a short critique of his view that builds on my analysis of the story.

\section{The Narrative Utterance and Argument: Ricoeur's Mistake}

In Time and Narrative, Ricoeur divides mimesis into three moments. Mimesis 1 (M1) addresses the pre-understandings of "the world of action, its meaningful structures, its symbolic

resources, and its temporal character." ${ }^{\prime 47}$ Mimesis 2 examines the emplotment, which mediates preunderstandings and readings (M2), while Mimesis 3, the reading, addresses "the intersection 
of the world of the text and the world of the hearer or reader." ${ }^{48}$ The reader's response to the text, M3, folds back into M1 as part of the new preunderstandings in the lifeworld, thus completing the hermeneutic circle.

In Mimesis 1, Ricoeur drives a wedge between narrative and experience in the world at the same time that he freezes the historical and dialogical character of language and literature. Ricoeur does not place the subject in language and narratives so that inchoate narratives already inform experience. To be sure, Ricoeur acknowledges that history and fiction "are preceded by the use of narrative in daily life." ${ }^{49}$ However, "prefiguration" is a cognitive capacity that stands against the experience of time, which in itself is "confused, unformed, and, at the limit, mute."50 For Ricoeur, we are not thrown into the narratives of the social imaginary. Thus, Mimesis 1 is "a structure of human praxis prior to the work of configuration by the historical or the fictional narrative." 51 This structure is informed by past narratives, past configurations.

Mimesis 2, or emplotment, is not an interpretive act through which the subject intervenes in the social imaginaries. Ricoeur develops his conception of the novel as emplotment without reference to imaginaries, the languages of public life or an ontological conception of meaning; instead, he draws on Aristotle's Poetics and on Kant's reflective judgment. Ricoeur isolates and reduces the configurational act to an ordering by the individual imagination: "I cannot overemphasize the kinship between this 'grasping together' power to the configurational act and what Kant says about the operation of judging." 52 Emplotment "extracts configuration from a succession" in the same that way that a reflective judgment "reflects upon the work of thinking at work in the aesthetic judgment of taste and the teleological judgment applied to organic wholes. $" 53$ In a stroke, Ricoeur has reduced the author's engagement with worth and truth of the languages of social imaginaries to a formal aestheticism. ${ }^{54}$ Thus, when he says that emplotment 
is the "synthesis of the heterogeneous"- that is, "the diverse mediations performed by the plot: between the manifold of events and the temporal unity of the story recounted between the disparate components of the action" 55 - the substantive epistemological, normative, and ontological issues that narratives engage become a merely reflexive ordering. By looking at narrative as the emplotment of the heterogeneous, Ricoeur blocks out the way in which emplotment is always a normative re-engagement with the narrative and symbolic shapes the subject inevitably already inhabits. Ricoeur keeps novelists out of the argument business, limiting them only to emplotment. "Historians are not simply narrators: they give reasons.... Poets also create plots that are held together by causal skeletons. But these ... are not the subject of a process of argumentation. Poets restrict themselves to producing the story and explaining by narrating [...]. [Poets] produce, [historians] argue.. ${ }^{, 56}$ Glaspell is not the only counter example to this claim. Proust — one of the novelists he discusses at length in Time and Narrative - makes extensive arguments against his realist predecessors both by explicit proposition and by narrative practice.

Since he conceives of narrative as the act of an isolated imagination, it is not surprising that Ricoeur's discussion of the novel in Time and Narrative and Oneself as Another is remarkably ahistorical. Despite the fact that the rise of the novel is embedded in issues of modernity itself, such as individualism, liberty, and language, Ricoeur ignores them all in his discussions of literature. For Ricoeur, novels are just examples of how the aporias of cosmic and experienced time are mediated by plot, or they are "thought experiments" in the Husserlian mold of imaginative variation in which our thrownness is ignored: "Literature proves to consist in a vast laboratory for thought experiments in which the sources of variation encompassed by narrative identity are put to the test of narration." ${ }^{57} \mathrm{We}$ are now ready for a very different 
example of how arguing through the social imaginary works, one that does not narrate the transition from one normative framework to another; instead, we see an aggressive confrontation of a dominant imaginative framework by alternative.

\section{Obama and the Discursive Constraints of Racial Politics}

I will begin with Barack Obama’s famous "race speech,” “A More Perfect Union,” and show the ways that it is tied to the discursive form of normativity laid down by Brown v. Board. I then examine how the work of Ta-Nehisi Coates exposes the ways this discursive form protects the majority from addressing the normative demands of African Americans.

When Obama himself addressed questions of race in his speeches, his language and reasoning were tied to the normative model of constitutional principles applied to particular situations, and this model harbors within it the tradition of silence on race that began with the gag orders prior to the Civil War. The model was given its modern discursive form in Brown v. Board of Education. ${ }^{58}$ In this argument for the American conception of equality, an admirable principle was bound with certain discursive constraints that occlude the world that Ta-Nehesi Coates, and his predecessors, such as Ralph Ellison, tried to expose. During the Brown deliberations, Chief Justice Earl Warren gave explicit recommendations to the other justices on the language of the decision: It "should be short, readable by the lay public, non-rhetorical, unemotional and, above all, nonaccusatory. ${ }^{, 59}$

The Brown decision was not only shaped by the silence about the perpetrators of racist acts, but by three other features of the discursive landscape. One was the way social scientific evidence was gathered and used. Brown's famous footnote 11 to Kenneth Clark's research, showing that adolescent black girls preferred white dolls to black ones, and to Gunnar Myrdal's American Dilemma. Both were used to establish the "damage hypothesis" and the language of 
victimhood as the appropriate lenses for addressing race. While these languages may have been effective in breaking down legal segregation, they were also effective in reinforcing condescension and inequality. The white majority could treat blacks as an object of pity, an approach that did little to challenge their own self-understanding. The American imagination could not conceive of injustice without victims, and whites did not recognize that they, not just African Americans, were damaged by racism. This disempowering condescension can be seen in the structure of many "progressive" literary works, such as To Kill a Mockingbird, in which we see black characters only from the point of view of whites, only as the objects of pity. The fact that this work served as a racial epiphany for many whites reveals how "recognizing" the evils of segregation can, at the same time, reinforce domination and misrecognition. ${ }^{60}$

In addition, Myrdal's work established a pattern of disregarding African American voices and seeing their culture as a pathological product of the slavery system. He claimed that African American culture "is a distorted development, or a pathological condition, of the general American culture." From this he concluded that it is to the advantage of African Americans as individuals and as a group to become assimilated into American culture. ${ }^{61}$ Myrdal's text encouraged white leaders to ignore the voices of African Americans and to urge blacks to abandon their culture and adapt to the dominant culture.

The third feature of the hegemonic American imagination was interest convergence-that is, blacks gained social justice primarily when their interests converged with the interests of the white majority. ${ }^{62}$ At the time of Brown, as is well-known, the United States' racial practices were a source of embarrassment in the Cold War because they undermined America's image abroad. ${ }^{63}$ These forces joined the first two elements mentioned to push the court and other elites to support desegregation without recognizing African American's autonomy or their voices. Interest 
convergence was not just a sociological phenomenon of domination; it became part of a discursive form that systematically silenced other forms of writing and living.

These three dimensions of American society hardened into a gag rule that continues today not only for the court but for mainstream media, though not for African American media, the black public sphere, and the black church. The mainstream media ignore these languages, for the most part, until such languages touch a person who is trying to succeed in the mainstream, such as a presidential candidate.

The exclusion of black voices from the mainstream media did not mean that African Americans did not speak out. From the time of the Civil War, the black public sphere has split in many ways from the mainstream public sphere. ${ }^{64}$ Black writers have taken up the political responsibility of writing in ways that challenge the dominant narratives of American public life. The first writer to respond directly to Myrdal's book was Ralph Ellison, and he directed his attack at Myrdal's reading of black culture: "Myrdal sees Negro culture and personality simply as the product of a "social pathology." While acknowledging that "Negro" culture has some undesirable features, Ellison insists in "An America Dilemma: A Review" that "there is much of great value and richness, which because it has been secreted by living and has made their lives more meaningful, Negroes will not willingly disregard." 65 Myrdal's misreadings lead him to assume that, in Ellison's words, "it is to the advantage of American Negroes as a group to become assimilated into American culture, to acquire the traits held in esteem by the dominant white Americans." ${ }^{66}$ For Ellison, neither white nor black culture can be affirmed in an unqualified way, for they are both damaged and imbricated in ways that go unnoticed: "What is needed in our country is not an exchange of pathologies but a change in the basis of society. This is a job which both Negroes and whites must perform together. In Negro culture there is much of 
value for America as a whole. ${ }^{967}$ Hence, American society needs neither mere integration of bodies into the same public spaces nor gathering statistics about inequality but a transformation of the social imaginary into which whites and blacks are integrated. Not surprisingly, Ellison saw the novel not as an "ordering of the heterogeneous," as Ricoeur would have it, or the disclosure of what cannot be said through conceptual assertions, in Taylor's view, but as an argument: "All novels of a given historical moment form an argument over the nature of reality and are, to an extent, criticisms of each other." ${ }^{68}$ Moreover, Ellison understood that revising the social imaginary (though he never used such a term) is a multidisciplinary affair. He not only took on Myrdal's sociological analysis of race, but also Howard Zinn's historical work, and Richard Wright's literary theory and practice. ${ }^{69}$

Thematizing the social imaginary as part of the deliberative process requires a new model for political deliberation, a model that calls the self-understanding behind Brown into question and brings new features of the world out of the background. This alternative way of understanding normativity is implicit in the works of Ellison, Wright, James Baldwin, Toni Morrison, and Ta-Nehisi Coates when we read them through this ontological perspective. These writers are not advocating a "politics of identity" or recognition but challenging the borders of America's normative imagination — precisely what Obama was compelled to avoid.

Obama's "race speech" in 2008 veers away from writings that challenge America's collective self-understandings and resorts to an updated version of the Brown model. The speech came after the media criticized the sermons given by Obama's minister, Reverend Jeremiah Wright, in which Wright expressed rage at America's failures. Wright's sermon was in the form of a "jeremiad," which has a long history in American and African American culture. From the 
Puritans to Frederick Douglas to Martin Luther King, this form has been used to criticize the promise and failures of America.

Reverend Wright's sermons were not part of a marginal, radical fringe. They were very well-known in the African American community and were even used as models for black divinity school. ${ }^{70}$ The criticism of Wright by the media displayed not only ignorance of the genre but, more importantly, a willful ignorance of African American speech and writing, whose normative claims challenged the dominant white identities and the historical understandings that underpin them. Obama alludes to the fissure between the discursive universes of blacks and whites in his speech: "The fact that so many people are surprised to hear that anger in some of Reverend Wright's sermons simply reminds us of the old truism that the most segregated hour in American life occurs on Sunday morning." "71 The oblivion of whites to Reverend Wright's form of speech is symptomatic of widespread oblivion about the reality of black lives. "Black lives matter" not only when they are being profiled and tased - the focus of attention in the news media_-but also when black people are speaking, acting, and laughing. ${ }^{72}$ When people respond to the cry of "black lives matter" with "all lives matter," they are simply repeating the legacy of Brown by offering an abstract normative principle while refusing to acknowledge the forceful normative structuring of American life.

Since black people appear in the collective imagination as a group that must be contained, pitied, and "helped" but never listened to, it is no wonder that Darren Wilson, the police officer in Ferguson, Missouri who shot the unarmed Michael Brown, told the jury that he shot Brown because he looked "like a demon," a force pushing back against the system. ${ }^{73}$ When mainstream media finally paid attention, their only question was to ask how anyone running for 
president could listen to such words regularly rather than asking how responsible media could ignore so many voices that challenged their self-understanding and conception of the world.

In his speech following the release of Wright's sermons, Obama does give voice to the anger and disappointment of blacks, but he is careful to balance it with the feelings of unhappy whites. Moreover, Obama recasts the long and brutal history of systemic and institutionalized racism as mere moral lapses. ${ }^{74} \mathrm{He}$ must affirm his patriotism and distance himself from language such as Wright's by placing this language and its rage at a historical distance from the present: "For the men and women of Reverend Wright's generation, the memories of humiliation and doubt and fear have not gone away; nor has the anger and the bitterness of those years. That anger may not get expressed in public, in front of white coworkers and white friends. But it does find voice in the barbershop or the beauty shop or around the kitchen tables ... and occasionally it finds voice in church on Sunday." 75

In order to support the notion of generational differences, as opposed to racial differences, Obama draws a parallel with his own white grandmother's occasional racist remarks. Wright's comments, like the racism on the white side of Obama's own family, are like the racism of a family member of a previous generation, a problem we all have. We can criticize them, but we cannot "disown" them. ${ }^{76}$ Moreover, he voices the anger of whites who do not feel that they have been privileged in a way that justifies affirmative action and other preferential treatments of African Americans ${ }^{77}$ Anger on both sides has proved "counterproductive" because the realization of all Americans' dreams is not a zero-sum game, in which realizing one dream comes at the expense of another. ${ }^{78} \mathrm{He}$ acknowledges that "disparities that exist between the African American community and the larger American community" and that "the inequalities passed on from an earlier generation suffered under the brutal legacy of slavery and Jim Crow."79 
However, when it comes to blame, he is careful to balance his criticism of whites with criticisms of blacks. ${ }^{80}$

Thus, when Obama notes that the Constitution "was ultimately unfinished. It was stained by this nation's original sin of slavery," he quickly adds that "the answer to the slavery question was already embedded within our Constitution - a Constitution that had at its very core the ideal of equal citizenship under the law." ${ }^{81}$ From his beginning with "we the people" to his anecdote of racial unity, Obama affirms what Jack Balkin calls the grand progressive narrative that dominates America's self-understanding: “America is continually striving for democratic ideals from its founding and eventually realizing democracy through its historical development. In this narrative, the constitution reflects America's deepest ideals, which are gradually realized through historical struggle and acts of political courage. The basic ideals of America and American people are good, even if Americans sometimes act unjustly." ${ }^{82}$ In Obama’s reading, constitutional principle can serve as the basis for an overlapping consensus among major religions. Obama says: "In the end, then what is called for is nothing more and nothing less than what all the world's great religions demand — that we do unto others as we would have them do unto us. Let us be our brother's keeper, scripture tells." 83 This ethical principle can be activated to address problems of race and difference through the idea of "empathy," through which universal principle addresses the particulars of individual lives.

Empathy follows from the constructivist understanding of equality because it depends on the capacity of the individual subject to project himself/herself into another's life. Defining it succinctly as a successful attempt to "stand in somebody else's shoes and see through their eyes," Obama regards empathy not as an exceptional gesture but an organizing principle for ethical behavior and even a preferred way of being. ${ }^{84}$ By cultivating our capacity for empathy, he 
says, we are forced beyond "our limited vision," making it possible to overcome what divides us, allowing us to "find common ground" even in the face of our sharpest disagreements. Obama makes empathy "the heart of my moral code" and "a guidepost for my politics" in The Audacity of Hope and in "A More Perfect Union." ${ }^{85}$ He ends his speech with the story of Ashley, in which a black man draws inspiration from a young white woman. The model of empathy fits well with thinking of normativity as the application of constitutional principles since it is organized around equal respect and concern for individuals. But this way of understanding normativity has failed to come to grips with the transsubjective normative structuring of the world. We need to come to grips with this understanding of normativity if we are to bring into view the racial structuring of society.

\section{Coates's Challenge to America's Dominant Racial Imaginary}

Ta-Nehisi Coates's book has been looked on as a direct reply to Obama's discussions of race. ${ }^{86}$ Coates makes this challenge not by a competing argument organized around principles of justice or equality. Instead, he reveals the normative languages that imprison African American lives, languages that include narratives, images, and characters. Against America's "progressive narrative" that Balkin identifies, Coates tells his son: "The entire narrative of this country argues against the truth of who you are." ${ }^{87}$ To Coates, these structures are the tissues of rationalization that encase the subjectivity of a privileged group that Coates calls "the Dreamers," alluding to the subtitle of The Audacity of Hope: Reclaiming the American Dream, as well as other versions of this dream. The dreamers are a self-contained community that does not think of itself as a community, but whose inhabitants live in a distinctive normative universe. Because their privilege, empowerment, and normative insularity are invisible to them, this universe is the site for pronouncements about "justice" and "equality" for society as a whole. 
To capture the self-understanding of the Dreamers, Coates cites Solzhenitsyn's wellknown remark that "to do evil a human being must first of all believe that what he's doing is good, or else that it's a well-considered act in conformity with natural law." Coates then comments: "This is the foundation of the Dream — its adherents must not just believe in it but believe that it is just, believe that their possession of the dream is the natural result of grit, honor, and good works. There is a passing acknowledgment of the bad old days, which, by the way, were not so bad as to have any ongoing effect on our present. The mettle that it takes to look away from the horror of our prison system, from police forces transformed into armies, from the long war against the black body, is not forged overnight. This is the practiced habit." ${ }^{88}$

Constitutional principles cannot root out inequality for it is woven into the language of the Dreamers' world. No thought experiment can lift a Dreamer out of this world or bring an outsider in. A Dreamer cannot empathize with the kind of life Coates is describing because the Dreamer needs a new framework for understanding normativity so that the "facts" of a nondreamer's life can appear. Coates is not appealing to a politics of identity but thematizing the ontological force of the reigning normative order. ${ }^{89}$

Thus, when he speaks of the police violence and of talk about sensitivity training, he is dismissive because such localization of the problem misses the point. It is not the police who commit the crimes but the American people locked in the dreamer imaginary: "The truth is that the police reflect America in all of its will and fear, and whatever we might make of this country's criminal justice policy, it cannot be said that it was imposed by a repressive minority. The abuses that have followed from these policies - the sprawling carceral state, the random detentions of black people, the torture of suspects—are the product of democratic will." 90 Coates's language is at once descriptive and normative. He wants to make clear that the 
dominant collective imagination of most whites and many blacks provides a framework in which criminality is understood, a framework that is not shared by minorities. He calls this framework the product of "will" in order to insist on the collective intentionality at work here. ${ }^{91}$

Coates's argument here works in a very different way than we find in much legal and political theory on race, which, for my purposes here, can be conveniently divided into antidiscrimination and antidomination approaches. The antidiscrimination argument maintains that the law should be colorblind. ${ }^{92}$ The antisubordination thesis, on the other hand, argues that there are large patterns of racial subordination made available through sociological analysis, patterns that the antidiscrimination thesis systematically occludes by focusing on the intentions behind laws. Between the World and Me, by contrast, takes aim at the normative weight and shape of America's collective imagination that drives research in both of these popular conceptions but which is thematized by neither one. This is not to say that Coates's position is beyond challenge by any means. Rather, my point is that he provides a kind of normative argument that is unavailable by other approaches to normativity.

Coates's text is one in a long line of African American writings that have sought to shake readers loose from their frameworks. However, people do not give up frameworks easily, particularly frameworks of long standing such as the one which makes its reappearance yet again beneath the eloquence of Obama's speech, a reappearance that displays the contemporary form of America's continuing gag-order about race.

\section{Conclusion}

The ontological turn in political philosophy has offered important new approaches to the deep structures of past, present, and future societies. However, this line of thought has not produced a viable theory of the normative utterance that follows from this approach, leaving itself open to criticism for abstracting from the agency of particular actors and for adopting the 
ambiguous language of world disclosure. ${ }^{93}$ In this essay, I have proposed a way of thinking about the relationship of background structures to particular utterances that expands the ways we think about normativity and argument. Rather than splitting off normative claims from sociological and narrative approaches to political philosophy, I propose to look at normativity from the perspective of social imaginaries, the ontological background structures of a given society. In this view, normativity is inflected by the particular shapes of forms of life but those shapes are never simply social facts; rather, they are the contestable background of speech and action into which we are thrown. Prior to questions of principle or fact are the ontological questions that emerge from social imaginaries and through which we orient ourselves in the world. We cannot point to the normativity of social imaginaries through the lens of constructivist theory or through the language of political realism for the context in question is not empirical nor ideal.

This ontological conception responds to the dilemmas that emerge in arguments between constructivists and realists. Realists complain that constructivist conceptions of normativity are detached from reality, while constructivists complain that realists and contextualists do not give an adequate place to normativity. ${ }^{94}$ The ontological conception makes normativity historical and contextual but the context starts with the macro structures that make the world and normativity itself possible. In the work of Glaspell and Coates, we find not just concrete situations presented phenomenologically but also external description that engages the discursive structures that display the actors and their dilemmas. However, the texts do not just direct us to facts we already know; instead, they urge us to look at the background structures that make certain facts possible and that lock the characters in to their preconceptions - in "Jury," the women's understandings of gender, marriage, etc. and in Between the World and Me, the conflicting worlds of Dreamers and African Americans. In both texts, we saw how the understanding of 
normativity for a community at any given moment must understood not just as the slow emergence of macro structures imaginaries that we find in Taylor's analysis - public sphere, popular sovereignty, etc.,-- which is done from great historical height with attention to longue durée, for this view implies that imaginaries are simply the nourishing background for principles or the shared background that makes debate possible. Instead, we need to attend to the language the texts use to bring our attention to the ways imaginaries feed ontological divisions within a political community, divisions that are covered over by the received understandings of both the real world and how it should be evaluated. As the texts make these structures surface through the phenomenological presentation of the characters, the reader is encouraged to connect them not by pointing to particular individuals_- "I know someone just like that"— but to patterns, just as Mrs. Peters finds in Minnie's text not only a parallel with her own life but an articulation of violence toward women that has been systematically silenced by the structures of the imaginary. These structures are both realistic and normative since they make possible what world is available and the assessment of this world. ${ }^{95}$ Normative argument relies on bringing aspects of the world into view, not only on the application of principles.

In a similar way, Coates's Between the World and Me attacks the dominant American framework for understanding race for its failure to grasp the structures of black life, structures that are brought out through a phenomenological narrative. Coates's argument reveals insulating moral narratives - including constitutional ones--that protect the majority from facing the cruelty that is reproduced daily. Coates shows that the failure to understand is at once epistemic and normative, a house of privilege that is invisible to the inhabitants at the same time that it makes those outside invisible. Coates is being "realistic," but he is not presenting sociological facts and then arguing for why these facts indicate injustice. Rather, he is striking at the ontology that 
generates facts and norms and therefore opening a space for new historical and sociological questions that can follow up on his insights. Coates's text makes clear that the people holding on to identity politics are not African Americans asking for recognition; rather, the people playing identity politics are the Dreamers whose identity defines the boundaries and blindnesses of their world. Coates show how principles enable Dreamers to assume that they have access to all the normatively relevant aspects of the world and to rationalize their contented inaction. Persuading the Dreamers means getting them to change the imaginaries that sustain their identities. The depth of resistance to Coates's argument can be seen not just in his critics but in the effusive praise for a speech that conforms to America's template for deliberation about race, Obama's "A More Perfect Union.”

My argument for a new understanding of the normative utterance and social imaginaries is not just a matter of isolated examples. By showing the link between normativity and realism, my understanding of the problematic of the social imaginary provides a way to bring together and mediate the languages of history, literature, and sociology so that they can work together in normative argument. ${ }^{96} \mathrm{I}$ have focused here on the ways that a short story, a Supreme Court decision, a speech, and a letter can illuminate the ways the social imaginaries install meanings and norms and at the same time provide resources for their revision. ${ }^{97}$ However, arguments through the imaginary can also be done at the level of macro background history, such as we see in the competing accounts of secularity in the work of Taylor, Gauchet, Michael Allen Gillespie, and Mark Lilla. ${ }^{98}$ These arguments seek to change the background history, which, in turn, will affect many local debates. The problematic of the social imaginary enables us to understand that the normative utterance cannot be hived off from the worldhood of the world and that normativity is woven into the imaginary. The normative utterance is first and foremost an 
engagement with the languages and practices of the social imaginary, for the background is logically prior to normative propositions and sociological explanations. This means that normative argument must concern itself with the articulation this background and the discursive structures through which it is instantiated and challenged. Such arguments will not be as neat as a Supreme Court decision, but they will give us a lot more to argue with and about than in thought experiments to produce principles. Although I have developed these two examples to show some of the possibilities opened by the problematic of social imaginaries, I am not arguing for the abandonment of the language of principle in all situations; rather, this essay asks for the inclusion of new kinds of normative arguments that can hear and articulate the world's complexity in ways that other ways of thinking and writing cannot.

${ }^{1}$ I would like to thank several people for inviting me to give earlier versions of parts of this essay before stimulating interlocutors: Chiara Bottici at New School, for her invitation to speak in Philosophy Department's Colloquium Series, Michael Halberstam at the University of Buffalo Law School for his invitation to speak at the Baldy Center for Law and Public Policy, and Alfred Nordmann at Darmstadt University, for his invitation to speak in the Philosophy Colloquium Series.

${ }^{2}$ Carla Bagnoli defines the constructivist approach as follows: "Constructivism is the view that the moral principles we ought to accept or follow are the ones that agents would agree to or endorse were they to engage in a hypothetical or idealized process of rational deliberation." "Constructivism in Metaethics," Stanford Encyclopedia of Philosophy. 
http://plato.stanford.edu/entries/constructivism-metaethics/accessed, May 6, 2014. For realists, constructivism ignores and blocks out the philosophical and historical conditions of its emergence and practice. Bonnie Honig summarizes the realist and agonistic critique of constructivists, communitarians and others who "converge in their assumption that success lies in the elimination from a regime of dissonance, resistance, conflict, or struggle. They confine politics... to the juridical, administrative, or regulative tasks of stabilizing moral and political subjects, building consensus, maintaining agreements, or consolidating communities and identities." Political theory and the Displacement of Politics (Ithaca: Cornell University Press, 1993), 2.

${ }^{3}$ Cornelius Castoriadis says: "The imaginary of which I am speaking is...the unceasing and essentially undetermined (social-historical and psychic) creation of figures/forms/images, on the basis of which alone there can ever be a question of 'something.' What we call 'reality and 'rationality' are its works.” Imaginary Institution, trans. Kathleen Blamey (Cambridge: MIT, 1998), 3. This is the broader field of social signification within which rules, forms, and processes acquire their specific meanings. The concern with normative imaginaries distinguishes this group from agonistic democrats, such as Chantal Mouffe and Jacques Rancière.

${ }^{4}$ Christina Lafont says, "Our world disclosure seems unrevisable from within and inaccessible from without." "Critique and Disclosure," Telos 145 (2008): 170. Habermas says, "To the degree that the poetic, world-disclosing function of language gains primacy and structuring force, language escapes the structural constraints and communicative functions of everyday life.” Philosophical Discourse of Modernity, trans. Frederick Lawrence (Cambridge: MIT Press, 1987), 204. 
${ }^{5}$ Chiara Bottici brings out the tension nicely, "The concept of imagination stands within a philosophy of the subject, whereas the concept of the imaginary signals a new distance from such view. There seems to be no way out—if one starts with 'imagination' conceived of as an individual faculty, then the problem is how to conceive of relation between individual imagination and the social context. If we begin with concept of social imagination, then the problem is how to reconcile with free imagination of individuals." Imaginal Politics (New York: Columbia University Press, 2014), 12. Bottici proposes the imaginal as a solution, while I think the utterance is better complement to the social imaginary. It is important to note that Castoriadis does not play the individual imagination off against social imaginaries and brings out the capacity for contesting imaginaries. I do not have space to discuss his complex work-which develops in a different direction than my own.

${ }^{6}$ John Rawls himself admits: "Not everything can be constructed. Every construction has a basis, certain materials, as it were from which it begins." Collected Papers, Revised Ed. (Cambridge: Harvard University Press, 2001), 514.

${ }^{7}$ Charles Taylor, Modern Social Imaginaries (Durham: Duke University Press, 2004), 2 , 8-9.

${ }^{8}$ Taylor, “Afterword,” In Varieties of Secularism (Cambridge: Harvard University Press, 2010), 308. Imaginaries are the middle level of articulation, between the "explicit doctrines about society, the divine or the cosmos" and "embodied understanding," or "habitus." (Taylor, "Two Theories of Modernity," Public Culture 11 (1999): 167.

${ }^{9}$ Charles Taylor, A Secular Age (Cambridge: Harvard University Press, 2007), 387.

${ }^{10}$ Charles Taylor, Sources of the Self (Cambridge: Harvard University Press, 1989), 26.

${ }^{11}$ Charles Taylor, Philosophical Arguments (Cambridge: Harvard University Press, 1997), 14-15. These are not "characterizations of a fully independent object" but "attempts to 
formulate what is initially inchoate, or confused, or badly formulated. But this kind of formation or reformulation does not leave its object unchanged. To give a certain articulation is to shape our sense of what we hold important in a certain way." Charles Taylor, Language and Human Agency, (Cambridge: Cambridge University Press, 1985), 36.

${ }^{12}$ Taylor, Secular Age, 1.

${ }^{13}$ Taylor, Secular Age, 3

${ }^{14}$ Taylor, Secular Age, 3

${ }^{15}$ John Rawls says, "Political liberalism assumes that, for political purposes, a plurality of reasonable yet incompatible comprehensive doctrines is the normal result of the exercise of human reason within the framework of the free institutions of a constitutional democratic regime." Political Liberalism (New York: Columbia University Press, 1993), xvi. Moreover, Rawls claims, history has already shown that this is possible, "History tells of a plurality of not unreasonable comprehensive doctrines" (140).

${ }^{16}$ Charles Taylor, Philosophy and the Human Sciences (Cambridge: Cambridge University Press, 1985), 36. I have substituted "secularity" for the "negotiation" in this wellknown passage from Taylor's work since he is making the same point with secularity.

${ }^{17}$ Rawls gives his famous capsule summary of the background to liberalism in the introduction to Political Liberalism (New York: Columbia University Press, 1993), "Thus, the historical of origin of political liberalism... is the Reformation and its aftermath, with the long controversies over religious toleration in the sixteenth and seventeenth centuries" (xxiv).

${ }^{18}$ Taylor, Secular Age, 29.

${ }^{19}$ Taylor, Sources of the Self, 87. 
20 "World Disclosure" is a translation of Heidegger's various terms "Erschlossenheit," "Lichtung" and "Ereignis." Taylor uses the notion of disclosure because "we can't turn the background against which we think into an object for us. The task of reason has to be conceived differently, disclosing what it involves." Charles Taylor, Philosophical Arguments (Cambridge: Harvard University Press, 1997), 12.

${ }^{21}$ Nikolas Kompridis makes this important distinction: "World disclosure refers, with deliberate ambiguity, to a process which actually occurs at two different levels. At one level, it refers to the disclosure of an already interpreted, symbolically structured world; the world, that is, within which we always already find ourselves. At another level, it refers as much to the disclosure of new horizons of meaning as to the disclosure of previously hidden or unthematized dimensions of meaning." “On World Disclosure, Heidegger, Habermas, and Dewey,” in Thesis Eleven (1994), 37.

${ }^{22}$ Robert Brandom uses the phrase to summarize some general assumptions that he wants to endorse - " "the relativization of meaning to context in a very broad sense, the model of dialogue, meaning pluralism, the open-endedness and mutability of semantic perspectives." Tales of the Mighty Dead (Cambridge: Harvard University Press, 2002), 93-94. He adds, "But earning the entitlement to the commitments those platitudes express requires real work" (94). Brandom differs in many important ways from Gadamer. See Cristina Lafont's "Meaning and Interpretation: Can Brandomian Scorekeepers Be Gadamerian Hermeneuts?” Philosophy Compass 2 (2007): 1-13.

${ }^{23}$ Robert Brandom, "Reply to Taylor's 'Language Not Mysterious,"” in Reading Brandom: On Making it Explicit, eds. Bernhard Weiss and Jeremy Wanderer (New York: Routledge, 2010), 303. 
${ }^{24}$ Brandom, "Reply to Taylor," 302.

${ }^{25}$ Brandom, "Reply to Taylor," 301. The reference here is to Ludwig Wittgenstein's Philosophical Investigations, $4^{\text {th }}$ ed. (Malden, MA: Blackwell, 2009): “Our language can be seen as an ancient city: a maze of little streets and squares, of old and new house, and of houses with additions from various periods; and this surrounded by a multitude of new boroughs with straight regular streets and uniform houses" (11).

${ }^{26}$ Taylor, “Language Not Mysterious," Reading Brandom, 43.

${ }^{27}$ Taylor, "Language Not Mysterious," 43.

${ }^{28}$ Taylor, "Language not Mysterious," 43.

${ }^{29}$ As Brandom says, Kant offers “a two-phase story, according to which one sort of activity institutes conceptual norms, and then another sort of activity applies those concepts. First, a reflective judgment (somehow) makes or finds the determinate rule that articulates [a] concept. Then, and only then, can that concept be applied in the determinate judgments and maxims that are the ultimate subject of the first two Critiques" "Some Pragmatist Themes in Hegel's Idealism: Negotiation and Administration in Hegel's Account of the Structure and Content of Conceptual Norms," European Journal of Philosophy 7 (1999), 166. Brandom's Hegel rejects this: "Our normative concepts are not instituted at the contractual level and then applied on the basis of the constitutive contract. They are instituted in the process of mutual recognition in which individuals hold one another responsible and implicitly impute to others the authority to keep normative track of one another's attitudes. This process does not need the social contract to get going or to get along” (“Some Pragmatist Themes,"166).

${ }^{30}$ Brandom, Tales of the Mighty Dead, 14.

${ }^{31}$ Taylor, Hegel, (Cambridge: Cambridge University Press, 1975), 467. 
32 Brandom, "Reply to Taylor," 302.

${ }^{33}$ Taylor, Sources of the Self, 510.

${ }^{34}$ Thomas Dixon's white supremacist novel The Clansmen, which served as the basis for D.W. Griffith's Birth of a Nation, would be an example of disclosive claims that are morally and politically repulsive. A theory of the social imaginary should be able to account for the argument that James Baldwin attributes to the film: "The Birth of a Nation is really an elaborate justification of mass murder;” The Price of the Ticket (New York: St. Martins, 1985), 584.

${ }^{35}$ Wolf Lepenies, Between Literature and Science: The Rise of Sociology (Cambridge: Cambridge University Press, 1988), 12.

36“Philosophy and Poetry," in The Relevance of the Beautiful and Other Essays, ed. Robert Bernasconi (Cambridge: Cambridge University Press, 1986), 134.

${ }^{37}$ Ibid., 133.

${ }^{38}$ Language Animal (Cambridge: Harvard University Press, 2016), 44

39 Taylor, Language Animal, 46.

${ }^{40}$ Taylor, Language Animal, 237.

${ }^{41}$ Taylor, The Language Animal, 292. Taylor does not give an account of narrative, usually footnoting Paul Ricoeur when the issue comes up. I will return to Ricoeur and narrative after I analyze the story and establish my counterargument.

${ }^{42}$ Taylor repeats the notion that imaginaries are produced by schematization in “Afterword," Varieties, 313).

${ }^{43}$ What lies behind Taylor and Dreyfus's position is the latter's debate with John McDowell over the place of the conceptual in phenomenology. John McDowell maintains that 
"conceptual rationality is everywhere in our lives, in so far as our lives are distinctively human, cannot be unmasked as a myth on the ground that it commits us to ignoring embodied coping skills" (Inquiry 50 [2007], 349). See Mind, Reason, and Being-in-the-World: The McDowellDreyfus Debate, ed. Joseph K. Schear (New York: Routledge, 2013), for the Dreyfus-McDowell exchange and commentaries by other philosophers. This debate is too complex to recapitulate here.

${ }^{44}$ Glaspell, “A Jury of Her Peers,” Best Short Stories of 1917_(Boston: Small, Maynard, 1918), 272.

${ }^{45}$ Philosophers, such as Martha Nussbaum and Robert Pippin, who assign all the normative work to philosophical principles and mere particularity and complication to literature, miss literature's normative arguments. I develop this critique through an analysis of their readings of Henry James in "The Philosophical Importance of Henry James's Late Style, “ The Henry James Review 35 (2014): 209-217

${ }^{46}$ In Empiricism and the Philosophy of Mind (Cambridge: Harvard University Press, 1997), he writes that "in characterizing an episode or a state as that of knowing, we are not giving an empirical description of that episode or state; we are placing it in the logical space of reasons, of justifying and being able to justify what one says" (76).

${ }^{47}$ Paul Ricoeur, Time and Narrative, trans. Kathleen Blaney and David Pellauer, 3 vols. (Chicago: University of Chicago Press, 1984-88), I: 54.

${ }^{48}$ Ricoeur, Time and Narrative, I: 71.

${ }^{49}$ Ricoeur, Time and Narrative, II: 156.

${ }^{50}$ Ricoeur, Time and Narrative, I: 14.

${ }^{51}$ Ricoeur, Time and Narrative, III: 310. 
${ }^{52}$ Ricoeur, Time and Narrative, I: 66.

${ }^{53}$ Ricoeur, Time and Narrative, I, 66.

${ }^{54}$ Many of these points follow directly from Ricoeur's commitment to methodological individualism, a fact that Taylor strangely never mentions.

${ }^{55}$ Ricoeur, Oneself as Another, trans. Kathleen Blamey, (Chicago: University of Chicago Press 1992), 141.

${ }^{56}$ Ricoeur, Time and Narrative, I:186.

${ }^{57}$ Ricoeur, Oneself as Another, 148.

${ }^{58}$ See Stephen Holmes, "Gag Rules, or the Politics of Omission, " in Constitutionalism and Democracy, ed. Jon Elster and Rune Slagstad (Cambridge: Cambridge University Press, 1988), 19-58; and Michael Gilmore, The War on Words: Slavery, Race, and Free Speech in American Literature (Chicago: University of Chicago Press, 2010).

${ }^{59}$ Quoted in Randall Kennedy, The Persistence of Race: Racial Politics and the Obama Presidency (New York: Random House, 2011), 121. As Kennedy observes: "If all we knew about segregation was what is discernible from the face of that ruling, one could be forgiven for wondering what was so wrong about 'separate but equal'” (121).

${ }^{60}$ The liberal political commentator James Carville recounts his epiphany: "I just knew, the minute I read it, that [Harper Lee] was right and I had been wrong." Cited in Eric Sundquist, "Blues for Atticus Finch," in The South as an American Problem, eds. Larry Griffin and Don Doyle (Athens: University of Georgia Press, 1995), 182.

${ }^{61}$ Myrdal, American Dilemma, revised ed., 2 vols. (Piscataway, NJ: Transaction Publishers, 1995) 2: 928-29. 
${ }^{62}$ The classic article is: Derrick Bell, "Brown v. Board of Education and the Interest Convergence Dilemma," Harvard Law Review 93 (1979-80): 518-33.

${ }^{63}$ President Eisenhower said in a 1957 televised address that the Cold War struggle and international opinion compelled him to send federal troops to Little Rock: "At a time when we face grave situations abroad because of the hatred communism bears toward a system of government based on human rights, it would be difficult to exaggerate the harm that is being done to the prestige and influence, and indeed to the safety, of our nation and the world. Our enemies are gloating over this incident and using it everywhere to misrepresent our whole nation. We are portrayed as a violator of those standards of conduct which the peoples of the world united to proclaim in the Charter of the United Nations." Cited in Kenneth Osgood, Total Cold War: Eisenhower's Secret Propaganda Battle at Home and Abroad. (Lawrence: University of of Kansas Press, 2006), 134.

${ }^{64}$ As David Blight observes: "In the half century after the war, as the sections reconciled, by and large, the races divided.” Race and Reunion, (Cambridge: Harvard University Press, 2001), 4.

${ }^{65}$ Ellison, Collected Essays, ed. John Callahan (New York: Modern Library, 1995), 340. ${ }^{66}$ Collected Essays, 339.

${ }^{67}$ Collected Essays, 340. Ellison insists that white culture has internalized, but not acknowledged, its borrowings from African American culture: "Whatever else the true American is, he is also somehow black" (Collected Essays, 583).

${ }^{68}$ Collected Essays, 165.

${ }^{69}$ See Ellison's critique of Howard Zinn's The Southern Mystique, "If the Twain Shall Meet," Collected Essays, 563-576. For his critique of Wright, see "The World and the Jug," 
Collected Essays, 155-188. He dramatizes this critique in the writing of his novel Invisible Man, whose title plays off Wright's Black Boy and Native Son.

${ }^{70}$ See Obery M. Hendricks, Jr. “A More Perfect (High-Tech) Lynching,” in which he discusses the demonization of Wright. Before the press attacked him, "Wright was a much-sought-after speaker at church revivals and conferences and even academic symposia .... He was awarded eight honorary degrees .... His four books are regularly found in course syllabi at theological institutions." In The Speech: Race and Barack Obama's “A More Perfect Union," ed. T. Denan Sharpley-Whiting (New York: Bloomsbury, 2009), 165.

${ }^{71}$ Barack Obama, “A More Perfect Union,” in The Speech: Race and Barack Obama's "A More Perfect Union," ed. T. Denan Sharpley-Whiting (New York: Bloomsbury, 2009), 245.

72 The Black Lives Matter movement has brought attention to some of this structuring in its protests against the killings of black men by police, but it leaves out black women and profound normative problems of race. In order for black lives to matter, white society needs to do more than simply try to avoid its "negative stereotypes" and change policing tactics. It needs to attend to the language of African American lives and transform its self-understanding.

${ }^{73}$ Quoted in the Guardian, "Interview with Claudia Rankine," where she says: "Blackness in the white imagination has nothing to do with black people." The Guardian. "Interview with Claudia Rankine." http://www.theguardian.com/books/2015/dec/27/claudiarankine-poet-citizen-american-lyric-feature, accessed, February 20, 2016.

${ }^{74}$ For example, Obama repudiates Wright's "view that sees white racism as endemic." “A More Perfect Union,” 240.

\footnotetext{
${ }^{75}$ Obama, “A More Perfect Union,” 244-45.

${ }^{76}$ Obama, “A More Perfect Union,” 242.
} 
${ }^{77}$ Obama, “A More Perfect Union,” 245.

${ }^{78}$ Obama, “A More Perfect Union,” 246-47.

${ }^{79}$ Obama, "A More Perfect Union,” 243.

${ }^{80}$ We see a similar pattern in his address in the Ebenezer Baptist Church in which he balances black sins with white sins. Obama says: "And for most of this country's history, we in the African-American community have been at the receiving end of man's inhumanity to man. All of us understand intimately the insidious role that race still sometimes plays on the job and in the schools, in our health care system, and in our criminal justice system. And yet, if we are honest with ourselves, we must admit that none of our hands are entirely clean. If we're honest with ourselves, we'll acknowledge that our own community has not always been true to King's vision of a beloved community." Barack Obama, "Address in Ebenezer Baptist Church," January 21, 2008. http://www.cnn.com/2008/POLITICS/03/18/obama.transcript/.

${ }^{81}$ Obama, “A More Perfect Union,” 237.

${ }^{82}$ Jack Balkin, "Brown v. Board of Education: A Critical Introduction," in What Brown Should Have Said, ed. Jack Balkin (New York: New York University Press, 2001), 5.

${ }^{83}$ Obama, "A More Perfect Union," 238.

${ }^{84}$ Barack Obama, Audacity of Hope: Thoughts on Reclaiming the American Dream (New York: Random House, 2006), 66.

${ }^{85}$ The two quotes are from Obama, Audacity of Hope, 66 and 67.

${ }^{86}$ See John Paul Rollert, "Between the World and Me: Empathy is a Privilege." The Atlantic, Sept. 28, 2015. http://www.the-american-interest.com/2015/10/10/reading-coatesthinking-obama/; and Jeremey Mayer, "Reading Coates, Thinking Obama," The American 
Prospect 11, no. 2 (October 10, 2015) http://www.the-american-

interest.com/2015/10/10/reading-coates-thinking-obama/, for the connection between Coates and Obama, who is never mentioned by name in Between the World and Me.

${ }^{87}$ Ta-Nehisi Coates, Between the World and Me (New York: Spiegel and Grau, 2015), 99.

${ }^{88}$ Coates, Between the World and $M e, 98$.

${ }^{89}$ Some have questioned Coates's apparent determinism, in which both blacks and whites are denied agency. Chatterton Williams notes: "It's not just black kids in tough neighborhoods who are hapless automatons." "Loaded Dice," London Review of Books 37, no. 2 (2015): 15-18. Williams is missing the point. Of course, people have agency, but what everyone has been overlooking are the structural properties of their world that shape that agency. Coates' text can reveal truth not by fidelity to particularities but by bringing into relief what is surreptitiously shaping our world.

${ }^{90}$ Coates, Between the World and Me, 79.

${ }^{91}$ David Brooks's response to Coates illustrates beautifully how "Dreamers" can avoid the challenge of Between the World and Me. Brooks writes: "I think you distort American history. This country, like each person in it, is a mixture of glory and shame. There's a Lincoln for every Jefferson Davis and a Harlem Children's Zone for every K.K.K.—and usually vastly more than one. Violence is embedded in America, but it is not close to the totality of America." "Listening to Ta-Nehisi Coates While White," The New York Times, July 17, 2015, http://www.nytimes.com/2015/07/17/opinion/listening-to-ta-nehisi-coates-whilewhite.html? r $=0$.

${ }^{92}$ Robert Post says, "The image of the orchestra audition distills the logic of American antidiscrimination law.” Prejudicial Appearances (Durham: Duke University Press, 2001), 19. 
See Reva Siegel, "Equality Talk: Antisubordination and Anticlassification Values in

Constitutional Struggles over Brown," 117 Harvard Law Review 1470 (2003-4), 1470-1547 for a discussion of both perspectives.

${ }^{93}$ See Lois McNay's The Misguided Search for the Political (Cambridge: Polity, 2014) for a critique of the "social weightlessness" of the ontological turn in politics.

${ }^{94}$ Geuss says that a realist will "start from an account of our existing motivations and our political and social institutions (not from a set of abstract 'rights' or from our 'intuitions.' Philosophy and Real Politics, 59. The problematic of the imaginary also begins with existing motivations and institutions, but it develops the background that makes them possible. For an excellent survey of the realist-constructivist debate, see Political Philosophy versus History: Contextualism and Real Politics in Contemporary Political Thought, edited Jonathan Floyd and Marc Stears (Cambridge: Cambridge University Pres, 2011).

${ }^{95}$ As Jürgen Habermas succinctly puts the point: "The tension between normative approaches, which are constantly in danger of losing contact with social reality, and objectivist approaches, which screen out all normative aspects, can be taken as a caveat against fixating on one disciplinary point of view." Inclusion of the Other (Cambridge: MIT, 1998), 6-7.

${ }^{96}$ As Samuel Moyn makes clear: "The rise of social imaginary is a promising venture precisely because it has the right aspiration: to test and possibly even to overcome the distinction between representations and practices" ("Imaginary Intellectual History," Rethinking Modern European Intellectual History, eds. Darrin M. McMahon and Samuel Moyn, New York: Oxford University Press, 2014, 114. In his conception of the imaginary Moyn rightly insists that we do not dissolve ideas and concepts into "webs of meaning" (Geertz) or a structuralist network of signifiers and signifieds. 
${ }^{97}$ Even though he neglected the question of normativity, Mikhail Bahktin was concerned with how literature - specifically, the novel—could engage and orchestrate all the languages of the imaginary-literary, political, sociological, philosophical, etc. Bakhtin asks us to see that "what is realized in the novel is the process of coming to know one's own language as it is perceived in someone else's language, coming to known one's own conceptual horizon in someone else's conceptual horizon (Dialogic Imagination, trans. Caryl Emerson and Michael Holquist [Austin: University of Texas Press, 1981], 365). The novel is not concerned with merely capturing the speech of an era but with what he calls, "the image of language," which "reveals not only the reality of a given language but also, as it were its potential, its ideal limits" (Dialogic Imagination), 356.

${ }^{98}$ See Gillespie, The Theological Origins of Modernity (Chicago: University of Chicago Press, 2009) and Lilla, The Stillborn God (New York: Random House 2007). 